\title{
No Association between Merkel Cell Polymavirus Infection and Keratoacanthoma in Korean Patients
}

\author{
Dae-Kwang Kim*
}

\begin{abstract}
Objectives: Keratoacanthoma (KA) is a relatively common benign tumor and resembles squamous cell carcinoma (SCC). The definitive cause of KA remains unclear, but trauma, ultraviolet light, chemical carcinogens, human papillomavirus, genetic factors, and immunocompromised status have been implicated as etiologic or triggering factors. Merkel cell polyomavirus (MCPyV) is suspected to cause the majority of cases of Merkel cell carcinoma (MCC). MCPyV-DNA was found significantly more frequently in MCC and only found in about one fourth of KAs. In a recent study, MCPyV was found in Korean patients with MCC. The aim of this study was to determine the presence of MCPyV in Korean patients with KA. Methods: Paraffin-embedded tissue samples were analyzed for the presence of MCPyV-DNA by polymerase chain reaction (PCR). A total of 105 KA samples were analyzed. Results: A study of $\mathrm{MCPyV}$ has not been reported about KA in Korean cases. In the present study the MCPyV was not detected with KA in the Korean patients. Conclusions: This supports that KA and MCPyV are not related to each other and MCVyP is not a major factor in the pathogenesis of KA.
\end{abstract}

Keywords: Keratoacanthoma- merkel cell polymavirus- PCR detection

Asian Pac J Cancer Prev, 20 (5), 1299-1301

\section{Introduction}

Keratoacanthoma (KA) is a relatively common benign tumor, characterized by rapid growth over a few weeks to months, followed by spontaneous resolution over 4-6 months in most cases. KA closely resembles squamous cell carcinoma (SCC) but there have been debates about a distinction between KA and SCC. Most previous studies of skin tumors except KA were well done, but little is known about KA tumorigenesis.

The definitive cause of KA remains unclear; however, trauma (Pattee and Silvis, 2003), ultraviolet light (Canfield et al., 1985), chemical carcinogens (Letzel and Drexler, 1998), human papillomavirus (Lu et al., 1996; His et al., 1997; Youn et al., 2010), genetic factors (Kim et al., 2003; Ha et al., 2005), and immunocompromised status (Shamanin et al., 1996) have been implicated as etiologic or triggering factors.

Merkel cell polyomavirus (MCPyV) is suspected to cause the majority of cases of Merkel cell carcinoma (MCC), a rare but highly aggressive form of skin cancer. Approximately $80 \%$ of MCC tumors have been found to be infected with MCPyV (Feng et al., 2008; Kassem et al., 2008)

In a recent study, $\mathrm{MCPyV}$ was found in Korean patients with MCC. However, there was no association of MCPyV with SCC, basal cell carcinoma (BCC), actinic keratosis (AK and seborrheic keratosis (Chun et al., 2013). The aim of this study was to determine the presence of MCPyV in Korean patients with KA.

\section{Materials and Methods}

KA specimens were taken between 1998 and 2010 at the 3 medical centers (Keimyung University Dongsan Medical Center, Yeungnam University Medical Center and The Catholic University of Korea, College of Medicine). One hundred five paraffin embedded KA samples were provided. Approval was obtained from the institutional review board of The Catholic University of Korea, College of Medicine. There was no evidence of multiple or familial KA and no history of prior chemotherapy or visceral malignancy in the patient group.

DNA isolation was performed as described before using the QIAamp DNA mini kit (Qiagen, CA, USA). A PCR pre-mixture kit (Bioneer, Daejeon, Korea) was used for PCR. To detect MCPyV DNA, we used two sets of primers to target the large and small T-antigen region. Their primer sequence were as follows: 138 base-pair product (MCP138 forward 5'-GGTTAGAGATGCTGGAAATGACC-3' and reverse 5'-CAAATAAGCAGCAGTACCAGGC-3'), and 191 base pair product (MCP191 forward 
5'-CCACTTTATTATCTTAGCCCAT-3' and reverse 5'-TCCTTTTGGCTAGAACAGTGTC-3'). DNA quality was confirmed by PCR used GAPDH (forward 5'-CGTCTTCACCACCATGGAGA-3' and reverse 5'-CGGCCATCACGCCACAGTTT-3'). The positive control was used a Merkel cell carcinoma (MCC) sample with MCPyV, as a gift from Dr. Jee-Bum Lee, Professor of Chonnam National University, Korea (Chun et al., 2013). The two virial regions amplified by PCR were corresponded with the genomic sequence (GenBank: EU375803.1, MCP1: 1993 to 2184, MCP2: 2185 to 2322) of MCPyV.

\section{Results}

In this study to investigate the potential role of MCPyV in Korean KA patients, MCPyV-DNA was not detected in all 105 samples with KA. This result suggested that there is no association between $\mathrm{KA}$ and $\mathrm{MCPyV}$ in Koreans (Figure 1).

\section{Discussion}

In this study, we used PCR to investigate whether $\mathrm{MCPyV}$ was present in KA patients. In a previous report, MCPyV-DNA was found significantly more frequently in $\operatorname{MCC}(37 / 43,86.0 \%)$ and only found in about one fourth of KAs (12/42, 28.6\%) (Wieland et al., 2012). Although there was a limitation on the relatively small number of KA samples, its findings argued against a pathogenic role of $\mathrm{MCPyV}$ in KA development and suggested that sporadic PCR detection of MCPyV in KA most likely represents a coincidental infection with a widespread virus. Another study also debated the pathogenic role for human polyomavirus (BKPyV, JCPyV, KIPyV, WUPyV, MCPyV, TSPyV, HPyV6, 7 and 9) in KA and Spitz naevus (Haeggblom et al., 2017).

The MCPyV was first reported in $85 \%$ of Korean patients with MCC in 2013 (Chun et al., 2013). A study of MCPyV has not been reported about KA in Korean cases. In the present study the MCPyV-DNA was not detected with KA in the Korean patients. This means that KA and MCPyV are not related to each other and $\mathrm{MCVyP}$ is not a major factor in the pathogenesis of KA.

In conclusion, in this study, the absence of MCPyV-DNA in Korean patients with KA was confirmed by PCR analysis at first time. This result will be useful to clarify no relationship between MCPyV and KA. This does not exclude the possibility that these lesions still may be associated to yet other identified or unidentified viruses, and further studies are warranted.

\section{Conflict of interest}

The author declares no competing financial interests.

\section{Acknowledgements}

This work was supported by the grant from the National Research Foundation of Korea (NRF) Grant funded by the Korea Government (MSIP) (No. 2014R1A5A2010008).

\section{References}

Canfield PJ, Greenoak GE, Reeve VE, Gallagher CH (1985). Characterization of UV induced keratoacanthoma-like lesions in HRA/Skh-1 mice and their comparison with keratoacanthomas in man. Pathology, 17, 613-6.

Chun SM, Yun SJ, Lee SC, Won YH, Lee JB (2013). Merkel cell polyomavirus is frequently detected in korean patients with merkel cell carcinoma. Ann Dermatol, 25, 203-7.

Feng H, Shuda M, Chang Y, Moore PS (2008). Clonal integration of a polyomavirus in human Merkel cell carcinoma. Science, 319, 1096-100.

Ha TW, Han KH, Son DG, Kim SP, Kim DK (2005). Analysis of loss of heterozygosity in Korean patients with keratoacanthoma. J Korean Med Sci, 20, 340-3.

Haeggblom L, Franzén J, Näsman A(2017). Human polyomavirus DNA detection in keratoacanthoma and Spitz naevus: no evidence for a causal role. J Clin Pathol, 70, 451-3.

Hsi ED, Svoboda-Newman SM, Stern RA, Nickoloff BJ, Frank TS (1997). Detection of human papillomavirus DNA in keratoacanthomas by polymerase chain reaction. $A m J$ Dermatopathol, 9, 10-5.

Kassem A, Schöpflin A, Diaz C, et al (2008). Frequent detection of Merkel cell polyomavirus in human Merkel cell carcinomas and identification of a unique deletion in the VP1 gene. Cancer Res, 68, 5009-13.

Kim DK, Kim JY, Kim HT, Han KH, Shon DG (2003). A specific chromosome aberration in a keratoacanthoma. Cancer Genet Cytogenet, 142, 70-2.

Letzel S, Drexler H (1998). Occupationally related tumors in tar refinery workers. J Am Acad Dermatol, 39, 712-20.

Lu S, Syrjänen SL, Havu VK, Syrjänen S (1996). Known HPV types have no association with keratoacanthomas. Arch Dermatol Res, 288, 129-32.

Pattee SF, Silvis NG (2003). Keratoacanthoma developing in sites of previous trauma: a report of two cases and review

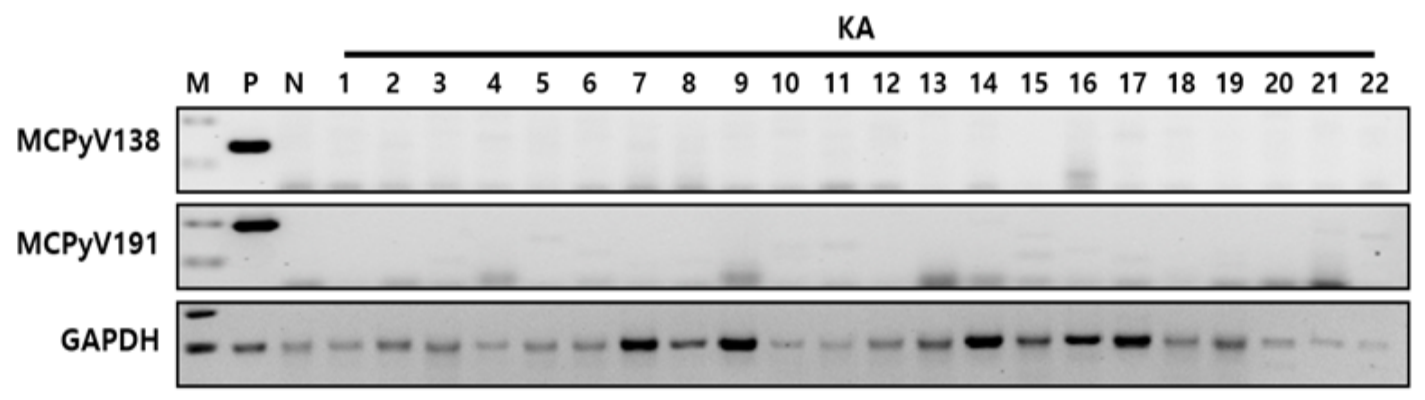

Figure 1. Merkel Cell Polyomavirus (MCPyV) DNA was not Detected in 105 Tissue Specimens from Keratoacanthoma (KA) Patients by Polymerase Chain Reaction with Two Sets of Primer (MCP138 and MCP 191). M, standard DNA marker; P, positive control DNA of MCPyV positive Merkel cell carcinoma; N, normal blood negative control DNA. 
of the literature. J Am Acad Dermatol, 48, 35-8.

Shamanin V, zur Hausen H, Lavergne D, et al (1996). Human papillomavirus infections in nonmelanoma skin cancers from renal transplant recipients and nonimmunosuppressed patients. J Natl Cancer Inst, 88, 802-11.

Wieland U, Scola N, Stolte B, et al (2012). No evidence for a causal role of Merkel cell polyomavirus in keratoacanthoma. J Am Acad Dermatol, 67, 41-6.

Youn SM, Lee JH, Park WS, et al (2011). No association between genital-mucosal human papilloma virus infection and keratoacanthoma in Korean patients. J Cutan Pathol, 38, 256-8.

\section{(ब) $(\mathbb{8}$}

This work is licensed under a Creative Commons AttributionNon Commercial 4.0 International License. 